\title{
KAJIAN PENGEMBANGAN TANAMAN Flacourtia inermis Roxb
}

\section{The Study of Flacourtia inermis Roxb Crop Development}

\author{
Joice Noviana Pelima \\ email : joicenoviana.p5@gmail.com \\ Fakultas Pertanian Universitas Kristen Tentena
}

\begin{abstract}
ABSTRAK
Tanaman Flacourtia inermis Roxb adalah species tanaman asli dari Asia dan Afrika yang beriklim tropis dan telah dimanfaatkan sebagai bahan pembuatan kue, jelly, sirup, manisan, selai,, acar, asinan dan rujak dan pengembangbiakannya secara generatif melalui biji. Pemanfaatan lain adalah sebagai bahan obat - obatan sesuai hasil penelitian di India yang menunjukkan bahwa ekstrak bagian dari tanaman $F$. inermis Roxb memiliki aktivitas antibakteri, antiviral, antitumor, antivenom,. antiptotozoa, antifungal, antibakteri, antibiotik, antioksidan dan aktivitas hipoglisemik. Berdasarkan hal tersebut maka pengembangan tanaman $F$. inermis Roxb meliputi aspek pengembangbiakan dan aspek pengelolaan pasca panen yang disertai dengan aplikasi bioteknologi pada masing - masing aspek pengembangan tersebut.
\end{abstract}

Kata Kunci : Flacortis inermis Roxb, Pengembangbiakan, Pengelolaan Pasca Panen

\section{PENDAHULUAN}

Tanaman Flacourtia inermis Roxb adalah species tanaman yang menghasilkan buah dan umumnya banyak ditemukan di wilayah Asia dan Afrika yang beriklim tropis. Jenis tanaman Flacourtia yang populer di wilayah India antara lain Flacourtia indica dikenal dengan nama Governor plum (Inggris), Flacourtia ramonchi, Flacourtia jangomas dengan nama Indian plum (India).

Di wilayah India, khusus untuk tanaman Flacourtia inermis Roxb terdapat 25 nama lokal. Di Malaysia mereka mengenal dengan nama rukam masam atau lovi - lovi karena buah dari tanaman F.inermis Roxb rasanya asam dan agak sepat sehingga orang Malaysia menyebutnya Flacourtia rukam sementara di Filipina mereka menyebutnya lovi - lovi atau batoko plum dan Thailand menyebutnya takhop - thai. Indonesia mengenalnya dengan nama lokal lobi lobi, tomi-tomi atau tome-tome.

Dari tempat asalnya di Asia Tenggara, Flacourtia tersebar dari India melalui Malaysia sampai ke New Britania selanjutnya menyebar ke bagian dunia yang lain termasuk Sri Lanka, Puerto Rico, Amerika selatan bagian utara, Florida dan China. Buah ini juga disukai di Karibia dimana masyarakat lokal memanfaatkannya untuk minuman dan pencuci mulut. Walaupun belum diketahui secara pasti orisinalitasnya namun ada anggapan bahwa tanaman ini secara alami lebih banyak terdapat di Asia dan mulai berkembang di daerah tropis Afrika serta Amerika Utara Selatan dan Florida. Tanaman Flacourtia banyak ditanam di Sri Lanka, Malaysia dan Indonesia. Di Indonesia tanaman ini menyebar mulai dari Maluku dan Papua Nugini..

Di Indonesia, buah tanaman $F$. inermis Roxb dimanfaatkan untuk bahan rujak dan biasanya sering dimakan mentah untuk buah yang sudah sangat matang karena rasa masamnya agak berkurang. Rasa buah yang agak masam dan sepat yang mungkin menyebabkan burung atau kelelawar kurang berminat sehingga penyebaran tanaman ini secara alami agak kurang dan mengakibatkan belum banyak ditemukan literatur ilmiah Indonesia yang menjelaskan secara rinci 
tentang buah ini. Informasi dari beberapa artikel baru sebatas menyebutkan pemanfaatan buah ini dan bahwa buah ini semakin langka di temukan karena tidak ada upaya pengembangannya.

Pada masa yang lalu tanaman ini sering ditanam di halaman rumah sebagai tanaman pekarangan. Namun saat ini semakin jarang ditemukan tumbuh di halaman rumah. Sedangkan di wilayah India penelitian terhadap buah $F$. inermis Roxb telah berkembang pesat. Dari hasil penelusuran literatur tentang penelitian

\section{PEMBAHASAN}

\section{Tanaman Flacourtia inermis Roxb}

Klasifikasi tanaman Flacourtia inermis Roxb ini adalah :

$\begin{array}{ll}\text { Kingdom } & \text { : Plantae } \\ \text { Divisi } & \text { : Angiospermae } \\ \text { Sub divisi } & \text { : Eudicots } \\ \text { Kelas } & \text { : Rosids } \\ \text { Ordo } & : \text { Malpighiales } \\ \text { Family } & \text { : Salicaceae } \\ \text { Genus } & \text { : Flacourtia } \\ \text { Species } & \text { : Flacourtia inermis Roxb }\end{array}$

Tanaman ini tergolong perenial dan berbentuk pohon yang tidak berduri dengan tinggi bisa mencapai $15 \mathrm{~m}$ berdiameter batang $35 \mathrm{~cm}$ dan percabangan dekat pada pangkal batang. Daun bundar telur lonjong sampai bundar telur jorong, panjang $8-20 \mathrm{~cm}$ dan lebar $4-12 \mathrm{~cm}$. Permukaan bagian atas hijau tua mengkilat, tulang tengah daun bagian bawah berbulu. Perbungaan aksiler terdiri dari tandan dengan beberapa bunga pada umumnya hermaprodit memiliki kelopak bunga 3 - 5 dan berbulu padat pada bagian sebelah dalam, benang sari 15 25 , tangkai putik $4-5$. Buah bani, blat, bergaris tengah $2-2,5 \mathrm{~cm}$, berwarna merah muda sampai merah. Biji $4-6$ dan memipih (Wikipedia Indonesia). buah $F$. inermis Roxb diketahui bahwa tanaman ini memiliki potensi sebagai sumber pangan jenis buah sekaligus berfungsi sebagai bahan dasar obat obatan. Oleh sebab itu penting untuk mengkaji pengembangan tanaman $F$. inermis Roxb untuk meningkatkan nilai komersialnya sehingga dapat mengurangi dominansi buah - buah import dan dapat menaikkan pamornya sebagai salah satu tanaman asli dari daerah tropis yang berdaya saing.

Tanaman ini hijau sepanjang tahun (evergreen) dan dapat tumbuh sampai pada ketinggian $1300 \mathrm{~m}$ di atas permukaan laut serta menyukai tanah kerikil berpasir. Banyak tumbuh dan berkembang di hutan lebat dan tumbuh baik pada suhu hangat serta tahan kekeringan tetapi menghindari kebekuan karena tidak tahan beku.

Menurut The Encyclopedia of Fruit and Nuts setiap $100 \mathrm{gr}$ buah segar mengandung $94 \mathrm{kkal}, 0.5 \mathrm{~g}$ protein, $0.6 \mathrm{~g}$ lemak, $24.2 \mathrm{~g}$ karbohidrat, $1.2 \mathrm{~g}$ serat, 33 $\mathrm{mg}$ kalsium, $0.7 \mathrm{mg}$ besi, $17 \mathrm{mg}$ fosfor, $171 \mathrm{mg}$ potassium, $5 \mathrm{mg}$ vitamin $\mathrm{C}, 0.01$ mg Thiamine/B1, 0.02 mg Riboflavin/B2. $.4 \mathrm{mg}$ Niacin/B3, 30 iu vitamin A (http://theindianvegan.blogspot.com).

Pengembangan tanaman

Flacourtia inermis dapat dilakukan pada aspek pengembangbiakan secara vegetatif dan generatif serta aplikasi bioteknologi untuk kebutuhan pemuliaan dan aspek pengelolaan pasca panen meliputi pengelolaan bahan pangan dan bahan obat-obatan.

\section{Aspek Pengembangbiakan}

Untuk mengembangbiakan tanaman $F$. inermis Roxb dapat dilakukan dengan perbanyakan tanaman secara vegetatif maupun secara generatif. Perbanyakan tanaman secara vegetatif dapat dilakukan dengan cara cangkok, 
stek dan sambung sedangkan perbanyakan secara generatif melalui biji.

Tanaman $F$. inermis Roxb adalah tanaman berkayu maka dengan mencangkok phloem akan terputus dan peredaran fotosintat terhenti sehingga mendorong terbentuknya kallus. Jika kallus menyentuh media yang basah akan merangsang terbentuknya akar. Cabang atau dahan tempat terbentuknya akar kemudian dipotong dan dipindahkan ke tanah sehingga diperoleh tanaman baru. Perbanyakan tanaman dengan cara stek adalah dengan menanam bagian batang, cabang, ranting dan pucuk. Perbanyakan tanaman dengan cara menyambung adalah menempatkan atau menyambung bagian tanaman ke bagian lainnya sehingga tercapai persenyawaan yang membentuk tanaman baru (Marjanin dan Hadmadi, 1983). Tujuan menyambung tanaman antara lain adalah untuk memperoleh tanaman yang cepat berbuah. Metode ini memerlukan kajian lebih lanjut untuk kelayakkan penerapannya dengan tujuan memenuhi kebutuhan produksi berskala besar.

Biji sebagai alat reproduksi tanaman F. inermis Roxb termasuk jenis biji memipih. Pengembangbiakan secara generatif tanaman ini ditujukan untuk kebutuhan riset cabang ilmu eksakta yang lain karena untuk mengembangkan tanaman ini dibutuhkan hasil kajian secara botanis, anatomis dan fisiologis. Sedangkan untuk kebutuhan produksi masal pengembangbiakan secara vegetatif adalah pilihan yang relatif baik.

$$
\text { Aplikasi bioteknologi untuk }
$$

reproduksi tanaman $F$. inermis Roxb adalah perbanyakan massal tanaman dan kebutuhan pemuliaan tanaman dengan teknik kultur jaringan. Dengan menerapkan teknik kultur jaringan pada tanaman ini diperoleh manfaat antara lain perbanyakan tanaman secara cepat sekaligus pelestarian plasma nutfah.

\section{Aspek Pengelolaan Pasca Panen}

Dari aspek pengelolaan pasca panen sebagai bahan pangan belum berkembang secara signifikan karena tanaman ini belum dibudidayakan dalam skala besar sehingga produksinya hanya mengharapkan hasil tanaman dengan jumlah terbatas dan dari tanaman yang tumbuh secara alami serta dipelihara turun temurun tanpa adanya peremajaan.

Buah F. inermis Roxb biasanya dimakan mentah walaupun asam dan sepat. Oleh karena itu diperlukan input bioteknologi untuk mengurangi rasa asam agar lebih disukai dan diminati konsumen. Dengan demikian semakin terbuka peluang besar untuk dikomersialkan. Buahnya cocok dibuat jelly, sirup dan manisan. Di tempat lain buah ini dimasak dengan apel untuk tambahan warna atau dibuat kue pie, jelly, selai, acar,asinan dan rujak seperti rujak natsepa di Ambon. Di wilayah Karibia, masyarakat lokal memanfaatkan buah ini untuk minuman dan sesajen. Flacourtia dengan kandungan pektin yang tinggi membuat buah ini ideal untuk membuat selai dan kolak.

Buah F. inermis Roxb tergolong buah bani yang memiliki $4-6$ biji. Hal ini merupakan kendala untuk meningkatkan nilai komersialnya sehingga untuk mengatasi jumlah biji dalam buahnya aplikasi bioteknologi yang diperlukan adalah menghasilkan buah tanpa biji. Untuk memperoleh buah tanpa biji dilakukan dengan menyilangkan tanaman yang tetraploid dengan tanaman diploid untuk mendapatkan tanaman triploid pada generasi pertamanya. Tanaman triploid dapat berbunga dan berbuah tapi tidak menghasilkan biji kalaupun ada biji namun hampa. Kegagalan tanaman menghasilkan biji adalah kegagalan pembentukan embryo pada proses gametogenesis yang merupakan 
penyimpangan proses biologis bagi tanaman (Jumin, 2005)

Di wilayah India sebagian besar jenis dari genus Flacourtia penting secara ekonomis. Selama bertahun - tahun buah ini banyak dimanfaatkan sebagai obat tradisional untuk mengobati beberapa jenis penyakit. Suku di India telah memanfaatkan tanaman ini sebagai obat mereka selama berabad-abad. Menurut hasil review oleh Gopi Chand Kota pada Prist University, orang miskin di pedesaan India menggiling biji Flacourtia dengan kunyit menjadi bubuk. Ramuan ini diberikan untuk wanita pasca melahirkan. Campuran ini diyakini dapat mengurangi rasa sakit rematik dan paparan lembab angin jika digosokkan di seluruh tubuh.

Saat ini sifat obat $F$. inermis Roxb semakin jelas karena dengan kulit berwarna ungu gelap sarat dengan polifenol dan flavonoid yang bermanfaat. Kandungan metabolik sekunder yang terdapat dalam buahnya seperti glukosida aromatik, glukosida lignanoid, diterpenoid dan glukosida sianohidrin. Senyawa senyawa ini menjadikan tanaman bersifat obat seperti antibakteri, antiviral, antitumor, antivenom dan aktivitas hipoglisemik. Dalam pengobatan tradisional Flacourtia bertindak sebagai perangsang nafsu makan diuretik dan pencernaan serta memerangi pembesaran limpa dan gejala penyakit kuning. Akar Flacourtia ini digunakan sebagai pendingin, alexipharmic dan depurative (http://theindianvegan.blogspot.com)

Hasil penelitian menunjukkan

bahwa F.inermis Roxb mengandung senyawa fenolik total $1,2 \mathrm{~g}$ setara dengan $100 \mathrm{gr}$ buah segar. Buahnya kaya akan antimicrobial agent-2,3-Dihydroxybenzoic acid.

Aktivitas senyawa kimia yang terkandung dalam buah $F$. inermis Roxb menurut beberapa hasil penelitian antara lain aktivitas antiptotozoa, aktivitas antifungal, aktivitas antibakteri, aktivitas antibiotik dan aktivitas antioksidan

Hasil penelitian menunjukkan bahwa semua protozoa yang diuji (Paramecium caudatum, Vorticella campanula) yaitu protozoa air mentah dan protozoa anus katak (Opalina rananum, Nyctoterrus cordiformis, Balantidium coli) sangat rentan terhadap ekstrak dengan konsentrasi $4 \mathrm{mg} / \mathrm{ml}$. Penelitian ini menyarankan bahwa buah ini prinsipnya mengandung antiprotozoa yang signifikan. Suatu hasil penelitian pada tahun 2010 yang diterbitkan oleh Journal of Ethnopharmacology menyatakan bahwa daun Flacourtia memiliki tiga senyawa anti malaria.

Penelitian yang dilakukan oleh Benny dkk, 2010 jelas memperlihatkan bahwa ekstrak buah $F$. inermis Roxb merupakan agen antifungal terbesar, dimana aktivitas tersebut lebih baik jika dibandingkan dengan agen antijamur berbasis tanaman. Prinsip pemurnian aktivitas dan penentuan MLC senyawa murni melawan patogen jamur perlu dievaluasi dan potensi alami antifungalnya

Penyaringan berbagai ekstrak buah $F$. inermis Roxb melawan strain standard memperlihatkan bahwa ektrak acetonik terdapat aktivitas antibakteri lebih tinggi. Semua mikroorganisme yang diuji secara sempurna sensitif terhadap hal itu walaupun mereka tahan terhadap kebanyakan antibiotik yang umum digunakan. Aktivitas ekstrak buah sama dengan spektrum besar antibiotik. Oleh karena itu, isolasi prinsip aktivitasnya. Uji toksikologi dan pharmacological penting sebelum menyarankannya sebagai agen antibakterial dengan skala luas untuk percobaan klinik. Selebihnya diperlukan penelitian dengan strain klinis untuk membuktikan keefektifan senyawa murni

Flacourtia inermis Roxb diduga memiliki potensi untuk dipergunakan sebagai agen pengendali gula darah 
berdasarkan hasil penelitian yang dilakukan oleh Alakolanga dkk (2015). Sebuah penelitian pada tahun 2010 yang dilakukan oleh American Eurasia Journal of Scientific Research menemukan bahwa daun Flacourtia mengandung antioksidan kuat, yang dapat memperlambat tandatanda penuaan dan mengurangi stres oksidatif bertanggung jawab untuk penyakit degeneratif. Penelitian yang dilakukan oleh Shibumon dkk (2011) memperlihatkan bahwa 2,3Dihydroxybenzoic acid yang diisolasi dari buah $F$. inermis Roxb merupakan antibiotik yang efektif melawan galur murni bakteri yang resisten (Shibumon, 2011).

Sebagaimana digambarkan dalam sebuah penelitian pada tahun 2010 yang diterbitkan oleh Indian Journal of Pharmacology bahwa pada ekstrak Flacourtia digambarkan berpotensi

\section{KESIMPULAN}

Tanaman Flacourtia inermis Roxb memiliki potensi yang beragam dan layak dikembangkan sebagai tanaman asli daerah tropis untuk menaikkan nilai ekonominya. Dengan aplikasi bioteknologi yang memadai khususnya pada aspek pengembangbiakan dan teknologi pengelolaan pasca panen maka tanaman Flacourtia inermis Roxb diharapkan dapat bersaing sebagai salah satu tanaman penghasil buah yang juga berfungsi sebagai bahan obat - obatan.

\section{DAFTAR PUSTAKA}

Alakolanga, Achala, L. Jayasinghe dan N. Savithri Kumar, 2015. Inhibition of Carbohidrate Hydrolyzing Enzyme Activities by Flacourtia Inermis Fruit Extract. International Conference on Agricultural, Ecological and Medical Sciences sebagai antihyperglycemic yang ampuh saat diujicoba pada tikus pengidap diabetes. Sebuah hasil penelitian pada tahun 2011 yang diterbitkan dalam Jurnal Afrika Dasar dan IImu Terapan menemukan potensi anti-asma ketika menguji ekstrak daun Flacourtia pada marmut. Dari hasil observasi manfaat Flacourtia dalam mengobati penyakit infeksi dan peradangan. Peneliti menguji senyawa yang terkandung dalam daun Flacourtia dan pada tahun 2011, menerbitkan sebuah hasil penelitian mereka dalam Jurnal Internasional Pengembangan dan Penelitian Obat yang menunjukkan bahwa tanaman Flacourtia mengandung antimikroba yang berarti dan kualitas antibakteri. Kayu tanaman $F$. inermis Roxb dipergunakan untuk bahan pembuatan rumah seperti di wilayah Halmahera.

(AEMS-2015) Feb. 10-11, 2015 Penang (Malaysia).

Benny PJ, Gerorge Shibumon, Kuriakose Sunny, George Cincy, 2010. 2,3Dihydroxybenzoic Acid: An Effective Antifungal Agent Isolated from Flacourtia inermis Fruit. International Journal of Pharmaceutical and Clinical Research 2010; 2(3) : 101 - 105.

Flacourtis inermis - Wikipedia, the free encyclopedia.

http://en.wikipedia.org

Jumin, Hasan Basri, 2005. Dasar - dasar Agronomi. Edisi Revisi. Jakarta: Rajawali Press.

Marjanin, M dan Hadmadi, M.Ed, 1983. IImu Hayat Dalam Pertanian Jilid I BOTANI. Jakarta : CV Yasaguna. 
Patro, Sanjeeb Kumar, Padmacharan Behera, Posa Mahesh Kumar, D. Sasmal, Ranjan Kumar Padhy, S.K . Dash, 2013. Pharmacological Review of Flacourtia sepiaria (Roxb). Scholar Academic Journal of Pharmacy (SAJP)., 2013; 2(2): 89-93

The Earth of India : All About Flacourtia diposting oleh Chaterine Reddy pada $\quad 7 \quad$ Oktober 2012 http://theindianvegan.blogspot.com diakses
Shibumon George, Benny PJ, Sunny Kuriokose, Cincy George, 2011. Antibiotic Activity of 2,3Dihydroxybenzoic Acid Isolated from Flacourtia inermis Fruit Against Multidrug Resistant Bacteria. Asian Journal of Pharmaceutical and Clinical Research Vol. 4, Issue 1, 2011

Zulkarnain, H, 2009. Kultur Jaringan Tanaman. Jakarta: PT. Bumi Aksara 